\title{
MPOD 法を用いたエンジンマウントの配置最適化*
}

\author{
福島広 隆*1, 鎌田慶宣*2, 萩 原一郎*3
}

\section{Optimum Engine Mounting Layout using MPOD}

\author{
Hirotaka FUKUSHIMA, Yoshinobu KAMADA and Ichiro HAGIWARA*4 \\ ${ }^{* 4}$ Department of Mechanical Sciences and Engineering, Tokyo Institute of Technology, \\ 2-12-1 O-okayama, Meguro-ku, Tokyo, 152-8552 Japan
}

\begin{abstract}
The Engine Mounting Layout is very important to provide the performance of NVH (Noise, Vibration, Harshness). In the conventional studies, the only un-coupling engine with the vehicle body is optimized. But we sometimes can't secure the performance of NVH when this engine is coupled with the body. So we need to use the analysis model made of the engine and the vehicle body. Usually these models need a long time for analysis. So we use CMS (Component Mode Synthesis) for the efficiency of the calculation. We use the MPOD (Most Probable Optimum Design) method using HNN (Holographic Neural Network) as the basic functions for this optimization problem of Engine Mounting Layout. Since this problem has as many design variables as 15 , it is needed many sampling data to get the global optimum design using any optimizing method. So we improve the MPOD to get the local optimum design with the fewer sampling data for reducing the cost of the calculation. We also improve HNN, because its theory has problem when we use higher order system of the basic functions.
\end{abstract}

Key Words : Engine Mounting Layout, NVH (Noise, Vibration, Harshness), CMS (Component Mode Synthesis), MPOD (Most Probable Optimum Design), HNN (Holographic Neural Network)

\section{1. 緒 論}

自動車の開発では, 騒音や振動, 乗り心地といっ たNVH性能の確保や耐久面一の配慮から, エンジ ンマウントも振動絶縁や振動エネルギー吸収を考え て設計されている.

従来のエンジンマウントの研究としては, パワー トレインとエンジンマウントから成るマウント系の 固有モードをまず非連成化し (1)，その非連成化さ れた固有モ一ドを車体モデルに組込み，マウント特 性を再調整することが一般的であった．しかしこの 方法では, 非連成化された 1 つのモートにエネルギ 一が集中する現象が生じ，その共振域レベルが急峻

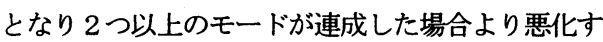
ることが，実車の開発ではよく経験されている．そ こで車体との連成を考虑し，アイドリング振動レベ ルなどの最終的な性能を直接的に目標値にできる方 法が必要である.これまでにもエンジンマウント采 と車体系との連成を考慮した報告もあるが車体は剛

* 原稿受付 2003 年 3 月 20 日.

*1 東京工業大学大学院 (-152-8552 東京都目野区大岡山 212-1).

*2 正員, 三菱自動車工業(株)車両実験部(-444-8501 岡崎市 橋目町中新切 1 )

*3 正員, フェロー, 東京工業大学大学院理工学研究科.

E-mail : hagiwara@ mech.titech.ac.jp
体と扱われていたり(2)，車軸方向第 1 次曲げモード と第 1 次ねじりモードの和でその特性を表現する(3) など厳密性を欠いている.

本報では車体との連成を考虑した，パワートレイ ン, エンジンマウント, 車体からなる車両系を解析 し，その振動レベルを目標値として，エンジンマウ ントの配置位置とその特性の最適化を試みている. その際, 車体モデルは $50 \mathrm{~Hz}$ までに含まれる全モー ドを表現できる程度に詳細な有限要素モデルとして いる. ただし大規模な車両系 FEM モデルを繰り返 し解くのではなく, 車体 FEM モデルとパワートレ イン FEM モデルを非拘束モーダルモデルに変換し， エンジンマウントを線形バネ要素と等価粘性減衰要 素としてモデル化して, 部分構造合成法(4)によって 諸特性を求めている. 最適化計算の中で変更される のはエンジンマウントのみであり, 予め計算されて いる車体, パワートレインの非拘束モードを用いれ ば，短時間で振動応答を計算することができる.

FEM モデルの節点にエンジンマウントを配置する ので, その值は離散值になる. 設計変数が離散值をと る最適化問題への解法として GA（遺伝的アルゴリズ ム）がよく利用されている，本報では，HNN (Holographic Neural Netwark) を基底関数とした最大 確率最適設計（Most Probable Optimal Design，以下 
MPOD(ら) 法を利用する. HNN の理論では，基底の 㹡張に伴い，回帰係数を一意的に推定できないという 問題点を解決し，また最適化では，目的関数の呼び出 し回数を低减するために, 必ずしも大域的な最適解と はならないが, 効果のある解, つまり次善の解への即 収束性を強めた MPOD法を提案する.

\section{HNN の理論とその搪張}

21 HNN の基理倫 HNNは, 入出力デー タを複素平面に写像する事により，入出力関係が線 形になることを利用したニューラルネットワークで あり，Sutherland 適化解析へ利用する方法が検討されている(

実数変数べクトル $\mathrm{x}$ 及び $\mathrm{y}$ を考える。 $\mathrm{x}, \mathrm{y}$ は $l$ 個の入力をもつ入力ベクトルと $m$ 個の出力をもつ 出カベクトルであり, 次式になる.

$$
\begin{aligned}
& \mathbf{x}=\left\{x_{1}, x_{2}, \ldots, x_{l}\right\}^{T} \\
& \mathbf{y}=\left\{y_{1}, y_{2}, \ldots, y_{m}\right\}^{T}
\end{aligned}
$$

$n$ 組の入出カベクトルをサンプリングデータとして

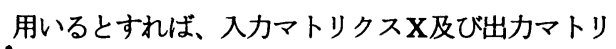
ククスYはそれぞれ式(3)，(4)のようになる.

$$
\begin{gathered}
\mathbf{X}=\left[\begin{array}{c}
\mathbf{x}_{1}^{T} \\
\vdots \\
\mathbf{x}_{n}^{T}
\end{array}\right]=\left[\begin{array}{cccc}
x_{11} & x_{12} & \cdots & x_{1 l} \\
x_{21} & x_{22} & \cdots & x_{2 l} \\
\vdots & \vdots & \ddots & \vdots \\
x_{n 1} & x_{n 2} & \cdots & x_{n l}
\end{array}\right] \\
\mathbf{Y}=\left[\begin{array}{c}
\mathbf{y}_{1}^{T} \\
\vdots \\
\mathbf{y}_{n}^{T}
\end{array}\right]=\left[\begin{array}{cccc}
y_{11} & y_{12} & \cdots & y_{1 m} \\
y_{21} & y_{22} & \cdots & y_{2 m} \\
\vdots & \vdots & \ddots & \vdots \\
y_{n 1} & y_{n 2} & \cdots & y_{n m}
\end{array}\right]
\end{gathered}
$$

$\mathrm{X}, \mathrm{Y}$ の各要素は, 任意の变換関数により位相 $\theta$ 及 び申へ変換される.

$$
\begin{aligned}
\theta_{k h} & =f\left(x_{k h}\right) \\
\phi_{k j} & =g\left(y_{k j}\right)
\end{aligned}
$$

次に指数関数により, 複素平面上に写像される.

$$
\begin{aligned}
s_{k h} & =\lambda_{k h} e^{i \theta_{k h}} \\
r_{k h} & =\gamma_{k h} e^{i \phi_{k t}}
\end{aligned}
$$

ここで $\mathrm{i}$ は虚数単位 $\left(\mathrm{i}^{2}=-1\right)$ である. 式(5) (8)の操 作により, 入出カマトリクスX，Yはそれぞれ複素 平面上に写像され， $\mathbf{S}, \mathbf{R}$ になる.

$$
\begin{aligned}
\mathbf{S} & =\left[\begin{array}{cccc}
s_{11} & s_{12} & \cdots & s_{1 l} \\
s_{21} & s_{22} & \cdots & s_{21} \\
\vdots & \vdots & \ddots & \vdots \\
s_{n 1} & s_{n 2} & \cdots & s_{n l}
\end{array}\right] \\
\mathbf{R} & =\left[\begin{array}{cccc}
r_{11} & r_{12} & \cdots & r_{1 m} \\
r_{21} & r_{22} & \cdots & r_{2 m} \\
\vdots & \vdots & \ddots & \vdots \\
r_{n 1} & r_{n 2} & \cdots & r_{n m}
\end{array}\right]
\end{aligned}
$$

$\mathbf{S}$ と $\mathbf{R}$ の間にある線形関係を回帰俰数マトリクス

H，誤差マトリクス $\Delta$ を用いて，表現すると次式に なる.

$$
\mathbf{R}=\mathbf{S} \cdot \mathbf{H}+\boldsymbol{\Delta}
$$

回帰係数 $\mathbf{H}$ は誤差 $\Delta$ が最小になるように推定され る.

$$
\mathbf{H}=\left(\mathbf{S}^{*} \mathbf{S}\right)^{-1} \mathbf{S}^{*} \mathbf{R}
$$

ここで师は共役転置を表す。ここでHを推定する ことを学習という. また求められた $\mathbf{H}$ を用いて, 未学習入力データUに対して, その出力の予測值 $\tilde{\mathbf{v}}$ を次式から求めることを予湖という.

$$
\tilde{\mathbf{v}}=\mathbf{U} \cdot \mathbf{H}
$$

$\tilde{\mathbf{v}}$ の実空間上の値は, 式(6)の写像関数の逆変換に より求まる.

22 基底関数の拡張 HNNの学習能力, つま り関数の近似能力は学習入力マトリクス $\mathbf{S}$ の列数, 自由度に大きく依存する. 自由度が増えれば, 複雑 な関数近似も容易となり, 近似誤差の減少が可能と なる. HNN では, 低次の基底関数から高次の基底 関数を合成し, 関数の自由度を増やしている. 高次 基底関数は低次基底関数の積, その積の共役からな る. 例えば $I=2$ の入力データは, 2 次までの拡張 により, 基底関数の総数は 12 個となる.

$$
\begin{aligned}
& \{S\}=\left\{e^{i \theta_{1}}, e^{i \theta_{2}}\right\} \\
& \Downarrow \\
& \{\bar{S}\}=\left\{e^{i \theta_{1}}, e^{i \theta_{2}}, e^{-i \theta_{1}}, e^{-i \theta_{2}}, e^{2 i \theta_{1}}, e^{2 i \theta_{2}}, e^{-2 i \theta_{1}},\right. \\
& \left.\quad e^{-2 i \theta_{2}}, e^{i\left(\theta_{1}+\theta_{2}\right)}, e^{i\left(\theta_{1}-\theta_{2}\right)}, e^{i\left(-\theta_{1}+\theta_{2}\right)}, e^{-i\left(\theta_{1}+\theta_{2}\right)}\right\}
\end{aligned}
$$

つまりフーリエ変換のように高次関数を重ね合わ せることにより，近似誤差を减少させている.この 拡張された入力マトリクス $\overline{\mathbf{S}}$ を用いて， $\mathbf{H}$ を推定 すると次式になる.

$$
\left(\overline{\mathbf{S}} \overline{\mathbf{S}}^{-} \mathbf{H}=\overline{\mathbf{S}}^{*} \mathbf{R}\right.
$$

ここで問題となるのが, $(\overline{\mathbf{S}} * \overline{\mathbf{S}})$ に逆行列が存在す るかどうかである. 逆行列が存在しない場合, 式 （15）を満たす $\mathrm{H}$ が無限に存在し，一意的に求める ことができない.このような問題に対する解法として, ムーアペンローズー般化逆行列の利用も考えられる。 この逆行列は近似誤差と $\left\|\mathbf{h}_{\mathbf{k}}\right\|^{2}(\mathrm{k}=1, \ldots, m)$ が最小にな るように決定され，次式になる. $\mathbf{h}_{\mathbf{k}}$ は $\mathrm{H}$ の列べク トルである。

$$
\hat{\mathbf{H}}_{M P}=\overline{\mathbf{S}}^{*} \overline{\mathbf{S}}\left(\overline{\mathbf{S}}^{*} \overline{\mathbf{S S}} \overline{\mathbf{S}}^{*}\right)_{G}^{-1} \overline{\mathbf{S}}^{*} \mathbf{R}
$$

ここで ( $)_{G}^{-1}$ は任意の一般化逆行列を表す。 
しかしこの $\widehat{\mathbf{H}}_{M P}$ を用いて, 予測を行うと, 予測 の悪化する場合がある. その例として，図1にあるよ うな関数例を用意した. この関数は設計変数を $2 つ も$ つ.この関数上から図 2 の印で示す 23 点のサンプ リングデータを用いて，近似関数を作成する.ムーア ペンローズー般化逆行列を用いて作成した近似関数を 図 3 に示寸. HNN の基底関数は 3 次まで拡張され, 基底の総数は 24 個となる. 図 1 と比較して, 曲面が かなり異なることが確認できる.これは NN に特有 な現象であるオーバーフィッティング現象が生じてい るからである. この現象は, サンプリーグデータを与 えられた基底関数に無理やり適合させた結果, サンプ リング点の近似は良くなるが，それ以外の領域が悪化 するものである. この現象が生じると予測としては, 利用できない.

23 ペナルティー俰数を用いる方法 ムーアペ ンローズー般化逆行列を用いる代わりに，次のような ペナルティー関数を定義する.

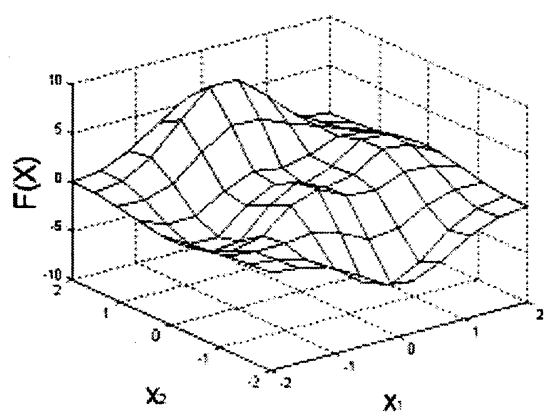

Fig.1 Visualization of Function used for Test

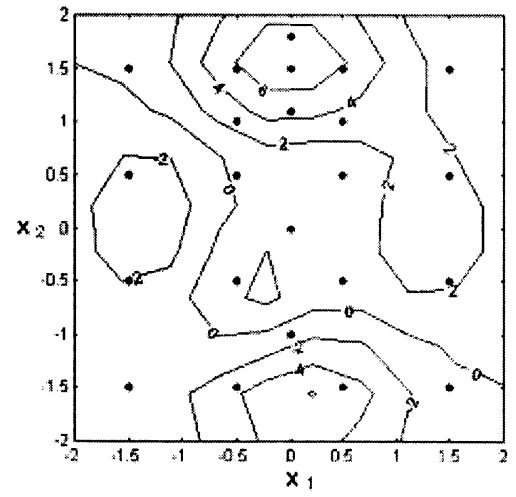

Fig.2 Layout of Sampling Point on Design Space

$$
\begin{array}{r}
f\left(\mathbf{h}_{k}\right)=\left(\mathbf{r}_{k}-S \mathbf{h}_{k}\right)^{*}\left(\mathbf{r}_{k}-S \mathbf{h}_{k}\right)+\rho_{1} \mathbf{h}_{k}^{*} O \mathbf{h}_{k}+\rho_{2} \mathbf{h}_{k}^{*} \mathbf{h}_{k} \\
(k=1, . ., m) \quad(17)
\end{array}
$$

ここで式中の行列 0 は要素がすべて 1 の正方行列で ある. この関数内の各項の意味は, 第 1 項が出力に対 する近似誤差, 第 2 項は回帰係数 $\mathbf{h}_{k}$ の平均, 第 3 項 はバラツキを表し, それぞれ係数 $\rho_{1}, \rho_{2}$ により重み 付けされている. 式(15)に対して Hに何らかの制約が ないと一意的に推定できないことから，このような条 件を追加した. 理論上, 第 2 項が無くても $\mathrm{H}$ は一意 的に推定できるが, 有るほうが安定的であった. 式 (17)からぺナルティー関数が最小になるよに， H を推 定すると次式になる.

$$
\hat{\mathbf{H}}_{P}=\left(\mathbf{S}^{*} \mathbf{S}+\rho_{1} \mathbf{O}+\rho_{2} \mathbf{I}\right)^{-1} \mathbf{S}^{*} \mathbf{R}
$$

ここでI は単位行列である. この $\hat{\mathbf{H}}_{P}$ を用いて, 同様 に 23 点のサンプリングデータから作成した近似関数 を図 4 に示す. 倸数 $\rho_{1}, \rho_{2}$ は共に 1.0 とした. 図 4

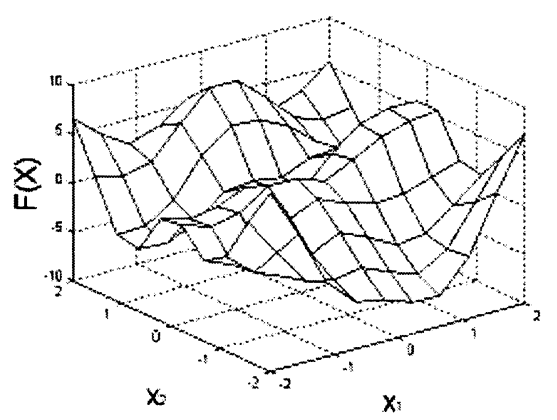

Fig3. Approximated Function using Moore and Penrose Generalized Inverse

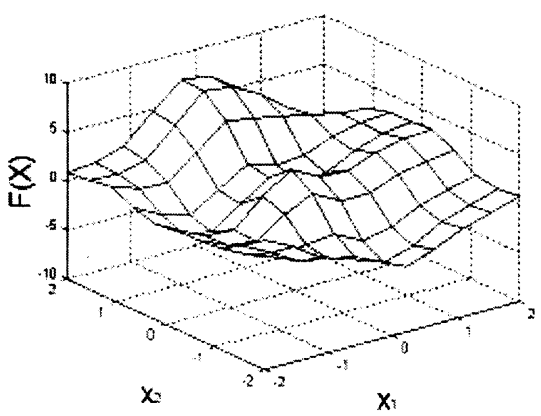

Fig.4 Approximated Function using Penalty Coefficient Method 
Table 1.Comparison between two methods by Square-Mean-Errar

\begin{tabular}{|l|c|c|}
\hline & $\hat{\mathbf{H}}_{M \boldsymbol{P}}$ & $\hat{\mathbf{H}}_{\boldsymbol{P}}$ \\
\hline Error in Learning & 0.0447 & 0.4993 \\
\hline Error in Prediction & 1.8681 & 0.9373 \\
\hline
\end{tabular}

ではオーバーフィッティング現象が生じずに，近似関 数を作成できている.

両手法による近似関数を数值的に平均 2 乗誤差を用 いて評価する.

$$
E=\sqrt{\frac{1}{N} \sum_{k=1}^{N}\left(y_{k}-\hat{y}_{k}\right)^{2}}
$$

ここで $N$ は評価点の数であり, 評価点における真 の関数值 $y_{i}$ と近似関数上の值 $\hat{y}_{i}$ の差を用いている.

誤差の評価点として, サンプリング点である 23 点だ けを用いたものを近似誤差, 設計領域を各 50 等分し た 2601 点を用いたものを予測誤差と呼ぶことにする. まとめたものを表 1 に示す. ムーアペンローズ一般化 逆行列を用いた場合, サンプリング点のみの誤差であ る近似誤差は非常に小さいが，予測誤差は悪化してい ることが判る. 一方, 提案したペナルティ係数を用い る方法では, 近似誤差はムーアペンローズ一般化逆行 列によるものより小さくないが，予測誤差を適度に抑 えられていることが判る。

24 ペナルティー俰数の大きさ提案した手法 では係数 $\rho_{1}, \rho_{2}$ の大きさをいくらにするかが重要と なる. 俰数 $\rho_{1}, \rho_{2}$ を非常に小さくした場合, ペナル ティー関数内の第 1 項, 近似誤差の重みが大きくなり, 近似誤差がより小さくなるように H が推定されるの で, 得られる近似関数はムーアペンローズ一般化逆行 列による近似関数に近づく. 逆に係数 $\rho_{1}, \rho_{2}$ を大き くしすぎると，第1項の重みが小さくなり，せっかく のサンプリングデータの情報が活かせなくなる. そこ で, サンプリングデータが多く設計領域から満遍なく 採られている場合は, 係数 $\rho_{1}, \rho_{2}$ を小さくし, 近似 誤差を减少させ, サンプリングデータによる情報を有 効に活用できるようにする. 一方, サンプリング数を 减らしたい場合は, 倸数 $\rho_{1}, \rho_{2}$ を適度に大きくし, オーバーフィッティング現象が生じないように, 少な い情報で設計領域を大まかに近似する.

\section{HNNを用いた最適化手法}

3.1 MPOD 法の概要 MPOD 法は応答曲面を求 めるためのサンプリング点の選択法を定義した方法で ある. サンプリング数の増減と得られる最適解の良し
悪しとのトレードオフの関係をとった確率的探索法で ある. 一般に多くの最適化手法では, 設計変数の数が 增えると, そのサンプリング数, つまり目的関数の計 算回数は増加する. この MPOD 法も例外ではなく, 設計変数が増えた時のサンプリング数の増加をなるべ く低减することが，計算コストの面から望まれる. 本研究で扱うエンジンマウントの最適配置問題は, 後で詳細を述べるが, 設計変数が 15 個と多い, そこ で MPOD 法の局所解への収束性をある程度強めて, サンプリング数の増加を抑えた即収束性をもつ MPOD法を提案する.

32 即収束性をもつMPOD法の概念 ここでは, サンプリング数を抑制するために，以下のような考え 方を利用している. 始めに用意した複数のサンプリン グデータにより, HNN により近似関数を作成する. その近似関数により予測された最適解に保証が存在す れば，終了とする.ここで保証とは，最適解と予想さ れたものが, 本当に効果があるかどうかである. HNN で近似させた場合に, サンプリング点のある領 域は近似が良いので，予想された最適解と似たような サンプリング点が既に存在すれば，その最適解の効果 は保証されていると考えられる. 稀に, 予想された最 適解の付近にサンプリング点が無くても，応答の予測 值と正解值が近い場合もあるが，他の領域にサンプリ ング点が追加され，近似関数が更新された場合に，ま た同じ予測值を返すという保証はない，そこで予測さ れた最適解に似たようなサンプリング点が存在しない 場合は, 保証がないと判定し, その最適解をサンプリ ング点として追加する.

この手法は，大域的最適解を探索するものではなく， 与えられたサンプリング情報からなるべく良いものを 予想する手法である.

3.3 即收束性をもつMPOD法の流れ 各操作を 説明し，文献（3）の MPOD 法の各ステップを基本 とする流れを図 5に示す.

【Step0 : 初期サンプリング点の選択】

設計範囲から一様分布乱数により， $N$ 個の初期サ ンプリング点を選択する. この時, 似たような点を 選ばないように, 各点間の距離を制限した式(20)の 条件を付加する. ここで $d_{\min }$ は許容最短距離であり, 始めは大きく設定されている. 式(20)を満たす点が 存在しない場合には, 次第に $d_{\text {min }}$ の大きさを小さく する. ただし $M$ は現在のサンプリング点の総数で ある. 設計変数の大きさによる影響を避けるために, 距離を計算する時は, 無次元化して用いている. 


$$
d_{\min } \leq \min \left(\left\|\mathbf{x}_{i}-\mathbf{x}_{j}\right\|\right), \quad(i, j=1,2, \ldots, M: i \neq j)
$$

また点数 $N$ をいくつにするかも重要な問題であ る. $N$ を大きくすれば, 設計領域から多くサンプリ ング点を採ることができるので, 局所解に陥る危険 性を低減できるが，その分の計算コストが掛かって しまう.

【Step1.1 : HNNへの学習と最適解の予測】

得られた学習点とその応答值の関係を HNNに学 習させ, 近似関数を作成する. 次に近似関数上の最 適解を探す，このときの探索手法としては，GAや SQP (逐次 2次計画) 法などが利用できる. GAの ように繰り返し計算の多い手法でも, 近似関数上の 応答值の計算は速いので，十分に対応できる．また 設計変数が離散值をとるような最適化問題でも，近 似関数上では連続なので, 感度を必要とする SQP 法などの手法も利用できる.

【Step1.2: Step1 の収束判定】

今得られた最適解を $\mathbf{x}_{k}^{*}$ とする. もしこの最適解 と似たようなサンプリング点が存在すれば, Step2 に行く.そうでなければ, この最適解をサンプリン グ点として追加して, Step1.1に行く.この時の判定 条件は式(21)で表せる.

$$
\min \left(\left\|\mathbf{x}^{*}-\mathbf{x}_{i}\right\| 1 i=1,2, \ldots, M\right) \leq \delta_{1}
$$

ここで $\delta_{1}$ は近接度を表す值である. 無次元化して 現在の最適解と各サンプリング点との距離を求めて いる.

\section{【Step2 : 最適化の終了判定】}

現在の最適解を $\mathbf{s x}_{k}=\mathbf{x}^{*}$ とおく．もし式(22)を満た していれば終了である.

$$
\left\|s \mathbf{x}_{k}-\mathbf{s} \mathbf{x}_{k-1}\right\| \leq \delta_{2}
$$

ここでs: $\mathbf{x}_{k-1}$ は前回 Step2 に来た時の最適解であり， $\delta_{2}$ は最適点の収束判定のしきい值である.

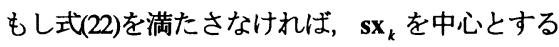
正規分布乱数により， $L$ 個の学習点を追加する. こ のとき分散 $\sigma_{i}$ は式(23)で決定する.

$$
\sigma_{i}=\alpha_{i}\left(s x_{k i}-s x_{k-1 i}\right) \quad(i=1,2, \ldots, L)
$$

ただし $L$ は設計変数の個数であり，このときも式 (20)の条件は付加される.

\section{4. 車両の数値解析モデル}

4.1 エンジンマウントのモデル化 本研究で は，図6に示すような重心支持マウントレイアウト

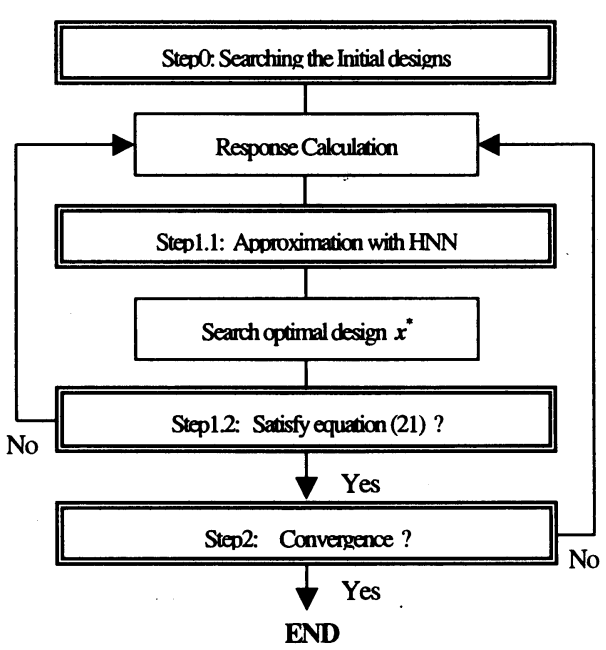

Fig.5 Flowchart of Optimal Method using MPOD

を想定している. これは主マウント 3 個でパワート レイン自重を支持するのが特徴である. このエンジ ンマウントを並進方向 $\mathrm{x}, \mathrm{y}, \mathrm{z}$ の線形バネ要素と等 価減衰要素でモデル化する. 質量はパワートレイン 系や車体系に比べて小さいので，無視する.

4.2. パワートレインの路析モデル パワート レインは車体に比べ剛性が十分に大きいので, 剛体 とみなして，6自由度の運動方程式で表し，6個の 剛体モードでこの部分要素を表現する.

43 車体解析モデル 図7に車体 FEMモデル を載せる. このモデルを MSCNASTRANにより固 有值解析して, $50 \mathrm{~Hz}$ 以下の解析周波数領域で抽出 される44個の固有モ一ドで車体部分を表現する.

4.4 完成車解析モデル エンジンマウントの バネ定数と減衰值, パワートレイン系と車体系それ ぞれの固有モード, 固有值と固有减衰係数を用いて, 部分構造合成法により完成車解析モデルを作成する. この完成車モデルは 50 個（=6+44）の自由度をも ち, 物理座標系の自由度に比べて, 非常に少ない自 由度で表現されている. また最適化の繰り返し計算 の中で, 変更される個所はエンジンマウントのみな ので、一度計算されたパワートレイン, 車体の固有 值, 固有モードはそのまま利用できる.

\section{5. 最適化問題の設定}

\section{1 設計変数の設定}




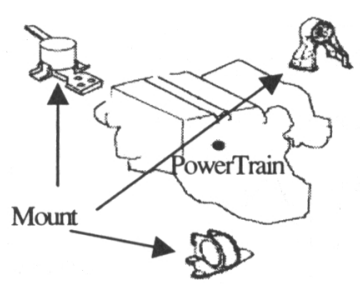

Fig.63 Mounts Model

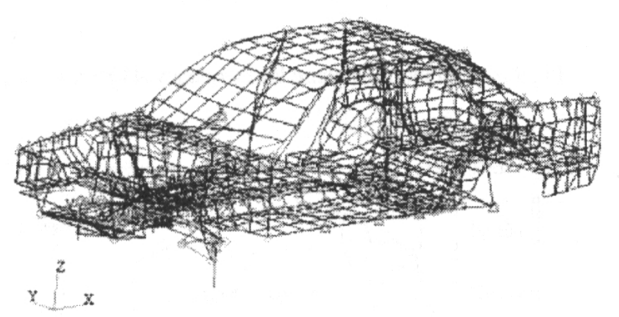

Fig.7 Vehicle FEM Model

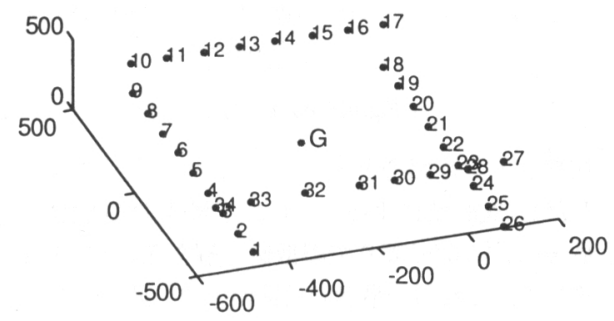

Fig8. Candidates for Location of Mounts

a. マウントの涀置位置図 8 にマウントの配置候 補の 34 箇所を示す.この候補地はパワートレイン を井むように配置されており，この中から 3 点を選 択する. 3 個のマウントの配置場所の番号を $P t_{l}$, $P t_{2}, P t_{3}$ とおくと次式の関係が成り立つ.

$$
1 \leqq P t_{1}<P t_{2}<P t_{3} \leqq 34
$$

3 個のマウントが近接して配㯰されると, パワート レイン自重の支持が不安定になる. そこでこれに対 処するために,

$$
\left\{\begin{array}{c}
P t_{2}-P t_{1} \geq 5 \\
P t_{3}-P t_{2} \geq 5 \\
P t_{1}+34-P t_{3} \geq 5
\end{array}\right.
$$

という制約をつける.

b. マウントのバネ定数と堿衰值 各マウントが 絶対座標系の $\mathrm{x}, \mathrm{y}, \mathrm{z}$ 方向のバネ定数と減衰值を持つ. これらの值は連続值として与える. マウント剛性に
は, アイドリング振動以外の性能を保証するために, 以下の静的な制約条件を設定する.

・エンジン始動時の過渡振動や加減速ショックに影 響する前後剛性

$$
\sum_{i=1}^{3} k_{x i}=35.0[\mathrm{kgf} / \mathrm{mm}]
$$

・操縦安定性に影響する左右剛性

$$
\sum_{i=1}^{3} k_{y i}=45.0[\mathrm{kgf} / \mathrm{mm}]
$$

・エンジンシェークに影響する上下剛性

$$
\sum_{i=1}^{3} k_{z i}=45.0[\mathrm{kgf} / \mathrm{mm}]
$$

ただし, $k_{d i}(d=x, y, z ; i=1,2,3)$ は $\mathrm{i}$ 番目のマウ ントの $\mathrm{d}$ 方向の剛性である。 また各剛性值, 減衰值 には上下限值があり，それらをまとめると以下のよ うになる。

$$
\left\{\begin{array}{l}
7.0 \leq k_{x i} \leq 21.0 \\
9.0 \leq k_{y i} \leq 27.0 \\
9.0 \leq k_{z i} \leq 27.0 \\
0.02 \leq c_{d i} \leq 0.1
\end{array} \quad(d=x, y, z ; i=1,2,3)\right.
$$

安定性のために, 減衰値にも剛性值同様の制約条 件を設けると，次式になる.

$$
\sum_{i=1}^{3} c_{d i}=0.1 \quad(d=x, y, z)
$$

全設計変数はマウント配置位置が 3 つに, 各マウ ントが 3 万向の剛性值, 減衰值をもつので, 計 21 個になる.しかし各方向の剛性値, 减衰値には線形 等式制約条件があるので，式(26)，(29)から

$$
\left\{\begin{array}{l}
k_{x 3}=35.0-\left(k_{x 1}+k_{x 2}\right) \\
14.0 \leq k_{x 1}+k_{x 2} \leq 28.0
\end{array}\right.
$$

のように変形できる．つまり計 21 個の設計変数と 6 個の線形等式制約条件が，計 15 個の設計変数と 6 個の境界条件に変形できる. 表 2 に 15 個の設計変 数を, 表 3 に6個の境界条件をまとめる.

5.2 目的関数の設定 アイドリング振動は主 に，乗員の着座しているシート取り付け位置で計測 されることから，座席を取り付ける車体クロスと左 右のサイドシルとの交点, 2点を観測点とする.こ の点における上下方向の振動加速度の周波数応答関 数ゲインは図9になる.

エンジンの冷態時までのアイドリング振動を考慮す ると，エンジン回転数は $600 \sim 900 \mathrm{rpm}$ の範井になり， 図 9 では $20 \sim 30 \mathrm{~Hz}$ の周波数範囲の振動に相当する. つまりこの周波数範囲の振動応答を下げたいので, 目的関数はこの範囲の周波数応答関数を, 周波数で 
Table2. 15 design variables

\begin{tabular}{|c|c|c|c|}
\hline & Mount1 & Mount2 & Mount3 \\
\hline Location & $P t_{l}$ & $P_{2}$ & $P_{t_{3}}$ \\
\hline Stiffness (x) & $k_{x l}$ & $k_{x 2}$ & \\
\hline Stiffness (y) & $k_{y l}$ & $k_{y 2}$ & \\
\hline Stiffness (z) & $k_{z l}$ & $k_{z 2}$ & \\
\hline Damper(x) & $c_{x l}$ & $c_{x 2}$ & \\
\hline Damper(y) & $c_{y l}$ & $c_{y 2}$ & \\
\hline Damper(z) & $c_{z l}$ & $c_{z 2}$ & \\
\hline
\end{tabular}

Table3. Boundary conditions

\begin{tabular}{|c|c|c|}
\hline Lower & & Upper \\
\hline 14.0 & $k_{x l}+k_{x 2}$ & 28.0 \\
\hline 18.0 & $k_{y l}+k_{y 2}$ & 36.0 \\
\hline 18.0 & $k_{z l}+k_{z 2}$ & 36.0 \\
\hline 0.04 & $c_{d l}+c_{d 2(d-x y x)}$ & 0.08 \\
\hline
\end{tabular}

Table4. Comparison between result of MPOD and one of GA

\begin{tabular}{|c|c|c|c|}
\hline & & MPOD & GA \\
\hline A & Response of Optimum Design & 0.244 & 0.240 \\
\hline B & Number of Sampling Points & 189 & 5000 \\
\hline C & Total Calculation Time [sec] & 1571.8 & 1256.8 \\
\hline D & $\begin{array}{c}\text { Calculation Time of Response } \\
\text { for all Sampling Points [sec] }\end{array}$ & 43.7 & 1150.0 \\
\hline E & Rete of D for C [\%] & 2.78 & 91.50 \\
\hline
\end{tabular}

積分したものを用いる．ただし観測点が 2 点あるの で，2点のこの積分值を足したものを目的関数とす る. 積分は $0.2 \mathrm{~Hz}$ 刻みの台形積分を用いている.

\section{6. 最適化結果}

6.1 MPODを用いた最適化手法への適用 ま ず初期サンプリング点として, $N$ 種類のマウントレ イアウトとその目的関数の応答值を求める. $N$ は式 (32)より求める. 式(32)は 2 次の多項式で近似するの に, 最低限必要な点数を表す.ここで $L$ は設計変数 の数である.

$$
N=\frac{(L+1)(L+2)}{2}
$$

$L=15$ とすると, $N=136$ となる. 各サンプリング点 は式(24), (25), (29)と表 2，3 からなる実行可能領域 内から採取する. 実行不能領域から集めないのは, 近似を良くしたい実行可能領域にサンプリング点を 集中させたいからである.

式(21)，(22)の $\delta_{1}, \delta_{2}$ を共に 0.05 に設定し，式(23) の $\alpha_{\mathrm{i}}$ を 1.5 としている. また HNNにより補間した 近似関数上の最適解を探索するのに, GA と SQP 法を併用している.SQP法は，GAによって得られ た解を初期点とした場合, 前回の最適解を初期点 にした場合とサンプリング点の中で最良のものを

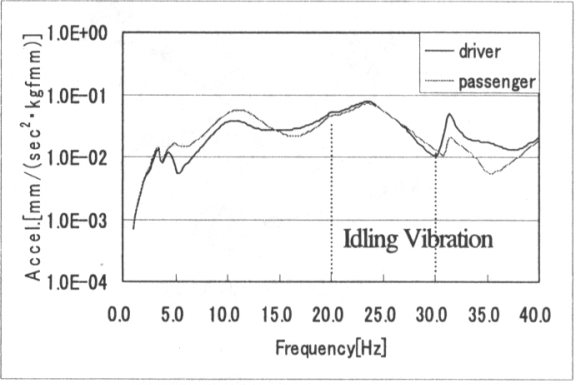

Fig.9 Acceleration Response for Frequency at Observating point

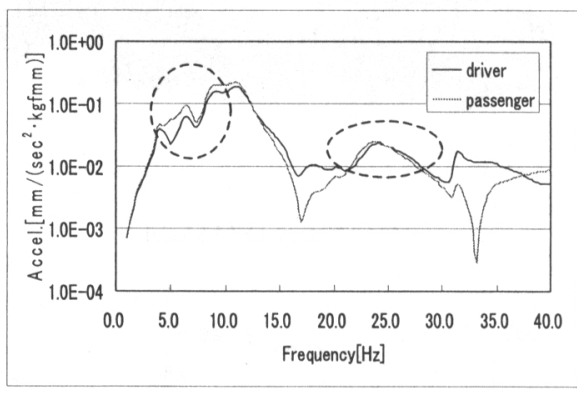

Fig.10 Optimized Response

初期点とした場合とで、計 3 回の実行をしている. ただし SQP 法によって得られる解は連続值なので、 最後にこの解の周りで離散値の解を探索している. そして, これらの最適解候補の中で, 最小のもの を各繰り返しでの最適解としている.

6.2 GAとの比較 MPOD法で得られた最適解の 有効性を確認するために, 同様の問題にGAを適用し た結果を示す.GAについては, 問題により様々な方 法が提案されている(8)が, ここでは基本的なものを利 用する. 実数型遺伝子でエリート保存戦略を採用し, 母集団サイズを 50 , 世代数を100としている. 表4に GAとMPOD法の結果を比較する. A 項では, 得られ た最適解の目的関数值を比較しているが，2つの值は 近く, MPOD法がGAと同程度の解を得られることの 確認ができる. B項では, 必要としたサンプリング数, つまり目的関数の計算回数を比較しているが, MPOD 法がGAより少ない.しかし全計算時間（C項）では, 逆転していることが判る. 今回の問題では1回あたり の目的関数の計算時間は約 0.23 秒である.これを用い て, 全目的関数の計算時間を求めると, D項になり, これが全計算時間に占める割合 (E項) は, MPOD法 が約3\%, GAが約 $90 \%$ となる，つまりGAの場合，1回 あたりの目的関数の計算時間が全計算時間に与える 
影響が大きい. 一方, MPOD法で最も時間のかかった プロセスは，毎回更新される近似関数上の最適解を 探すときであった. 近似関数に対してのGAは, 毎回 数秒で終了するが, SQP法は, 初期点によっては数分 かかる場合もあった. つまりMPOD法では, いかに効 率よく近似関数上の最適解を探すかが計算コストに 大きな影響を与えることが判る.

目的関数の計算時間がかかるような問題に対して は, サンプリング数，つまり目的関数の呼び出し回 数の少ないMPOD法が有効であるといえる.

63 最適化問題の拡張 図10に最適化された観 測点における周波数加速度応答ゲインを示す. アイ ドリング振動域である20〜30 Hzの応答は下げられて いるが，それより低い5〜15Hzの領域で悪化傾向にあ る. そこで.2節で定義した目的関数の積分範囲を 0 〜 30Hzに拡張した最適化問題を考える. 他の問題設定 は同じである.

今回は収束するまでに，サンプリング点は189点を 必要とし, 全計算時間は1547.6秒であった. この最適 化問題では, 1回あたりの目的関数の計算時間は約 0.69秒であり, 最初の問題と比べて約 0.46 秒の增加と なる. 仮にGAを適用した場合に, $5000 \times 0.46=2300$ 秒 の計算時間の増加となることから，MPOD法の計算時 間での有効性が確認できる.

最適化された応答を図11に示す，問題となってい た低周波数域の悪化を抑えて, アイドリング振動域 の低减が確認できる.

\section{7. 結 論}

（1）HNNの基底関数の拡張に伴い，回翚係数を 一意的に推定できない問題点に対して，サンプリン グデータの近似誤差と回帰係数のバラツキをペナル ティ保数で重み付けした誤差関数を定義した. この 誤差関数により推定される回州係数が，予測精度を 悪化させるオーバーフィッティング現象を回避しや すいことから，その有効性を示した.

(2) 多設計変数の最適化問題に MPOD 法を適用 するにあたり，サンプリング数の増大を抑制する方 法を提案した. GA との比較により,この手法がサ ンプリング数を抑えて，GA と同程度の解が得られ ることを確認した，計算時間に関しては，両手法の 特徵を示すことにより，問題に依存することを確認 した.

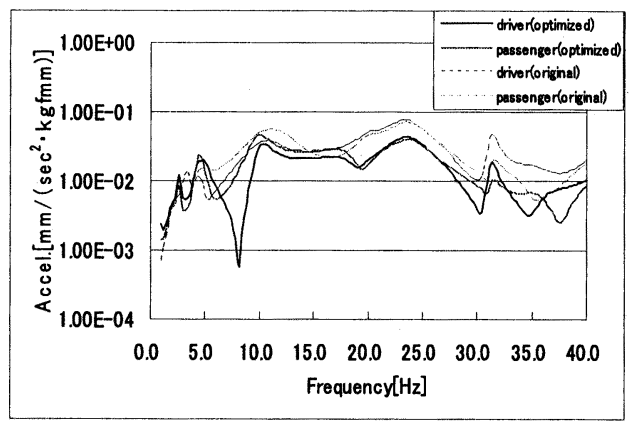

Fig.11 Optimized Response considerating Lower Frequency

（3）アイドリング振動の低减を目的としたエンジ ンマウントの最適配置問題では，低周波数域の悪化を 抑えたアイドリング振動の低减化ができた。

\section{文献}

(1) 酒井哲也・岩原光男・白井 裕・萩原一郎, 大 型車のエンジンマウントの最適設計(第 5 報, 遺 伝的アルゴリズムを用いたエンジンレイアウト の最適配置), 機論(C), 63 巻 664 号, pp.38153822, 2001

(2) T. Arai, T. Kubozuka and S. D. Gray, Development of An Engine Mount Optimization Method Using Modal Parameters, SAE Technical Paper 932898(1993).

(3) M. Ishihama, S. Satoh, K Seto and A. Nagamatsu, Vehicle Vibration Reduction by Transfer Function Phase Control on Hydraulic Engine Mounts, JSME Intemational Joumal Series C,Vol37,No.3(1994).pp.536-541.

（4）長松昭男 - 大熊政明，部分構造合成法，培風館， 1991

（5）施 勤忠・萩原一郎・高島 太, 応答曲面法 による多峰性問題の最適設計法の開発, 機論

(A), 65 巻 630 号, pp.232-239, 1999.

(6) J. G. Sutherland, The Holographic Model of Memory, Leaming and Expression, Intemational Joumal of Neural System, Vol.1,pp.259-267(1990).

(7) 萩原一郎・施勤忠・小机かかえ, 目的関数の二 ユーラルネットワーク推定による衝撃最適設計 法の開発, 機論(A), 63 巻 616 号, pp.2510-2517, 1997.

（8）坂和正敏・田中雅博, 遺伝的アルゴリズム, 日本ファジィ学会編「ソフトコンピューティン グシリーズ」, 朝倉書店, 1996. 